DOI: $10.17951 / \operatorname{lrp} .2016 .35 .4 .49$

\author{
BARBARA KALINOWSKA-WITEK
}

Uniwersytet Marii Curie-Skłodowskiej w Lublinie

\title{
WKŁAD ELIZY ORZESZKOWEJ W PROPAGOWANIE KWESTII KOBIECEJ ORAZ KSZTAŁTOWANIE DĄŻEŃ EDUKACYJNYCH MŁODYCH POLEK W II POŁOWIE XIX WIEKU
}

\begin{abstract}
Abstrakt: W II połowie XIX wieku na ziemiach polskich kwestia kobieca stała się ważnym tematem społecznym. Dotyczyła kobiet ze średnich warstw społecznych. Obejmowała zagadnienia kształcenia dziewcząt, przygotowania ich do działalności zarobkowej oraz znalezienia takich miejsc pracy, które będą odpowiednie dla kobiet i nie będą stanowiły konkurencji dla mężczyzn. Kwestie te poruszała również Eliza Orzeszkowa, znana pisarka i publicystka. Opowiadała się za gruntownym wykształceniem kobiet w kierunku odpowiadającym ich zdolnościom i zainteresowaniom. Domagała się reformy wychowania dziewcząt w rodzinie, a zwłaszcza zadbania o ich harmonijny rozwój fizyczny, umysłowy i moralny. Zwracała uwagę na popełniane przez rodziców błędy i wskazywała sposoby ich naprawienia. Przedstawiając w swoich powieściach i opowiadaniach losy kobiet, które zostały zmuszone przez warunki życiowe do podjęcia działalności zarobkowej, a nie posiadały do niej wymaganego przygotowania, podkreślała potrzebę zapewnienia każdej dziewczynie fachowego wykształcenia w wybranym przez nią kierunku. W tekstach publicystycznych wskazała cel oraz sposoby właściwego wychowania i kształcenia młodzieży żeńskiej. Wkład Elizy Orzeszkowej w propagowanie kwestii kobiecej oraz kształtowanie dążeń edukacyjnych młodych Polek w II połowie XIX wieku jest nie do przecenienia i dlatego stał się przedmiotem niniejszych rozważań.
\end{abstract}

Słowa kluczowe: Eliza Orzeszkowa, kwestia kobieca, kształcenie dziewcząt, praca zarobkowa kobiet 
W II połowie XIX wieku problem kształcenia dziewcząt i ich przygotowania do pracy zawodowej był niejednokrotnie poruszany na łamach czasopism, zwłaszcza kobiecych i rodzinnych. Wiązało się to z jednej strony z coraz powszechniej występującą ideą emancypacji, z drugiej zaś z potrzebą zapewnienia kobietom $\mathrm{z}$ warstw średnich możliwości podejmowania pracy zarobkowej. Było to o tyle istotne, że jeszcze w I połowie XIX wieku praca kobiet $\mathrm{z}$ warstwy posiadającej była uznawana za uwłaczającą godności rodziny i traktowana jako przejaw jej złej kondycji materialnej. Na ziemiach polskich, znajdujących się wówczas pod zaborami i zagrożonych licznymi represjami ze strony zaborców, dążenie kobiet do równouprawnienia w zakresie kształcenia i podejmowania zatrudnienia wiązało się przede wszystkim z koniecznością zdobycia środków na utrzymanie własne i rodziny. Rozwijająca się na Zachodzie Europy i w Stanach Zjednoczonych Ameryki idea emancypacji, postulująca zrównanie kobiet we wszystkich prawach z mężczyznami, miała dla Polek znaczenie marginalne. Kwestię kobiecą w jej polskim wydaniu przedstawiano również w literaturze pięknej. Pisarką i publicystką szczególnie popierającą dążenia kobiet do podejmowania pracy zarobkowej oraz wyjaśniającą kierujące nimi motywy była Eliza Orzeszkowa. Domagała się ona reformy wychowania i kształcenia kobiet $\mathrm{z}$ warstw średnich oraz przyznania im prawa do podejmowania pracy zarobkowej. Celem niniejszego opracowania jest zaprezentowanie wkładu Elizy Orzeszkowej w upowszechnienie kwestii kobiecej, a tym samym kształtowanie dążeń edukacyjnych Polek. Chociaż powieści i opowiadania E. Orzeszkowej doczekały się po II wojnie światowej wznowień - są więc dostępne dla zainteresowanych czytelników - dotarcie do jej tekstów publicystycznych wymaga znacznie większego wysiłku. Autorka podjęła się zatem zadania syntetycznego przedstawienia dorobku pisarki i publicystki, dotyczącego omawianego problemu. Pod koniec XIX wieku Polki podejmowały kształcenie na poziomie wyższym, a następnie konsekwentnie dążyły do podjęcia pracy w wyuczonych zawodach. Niewątpliwie przyczyniła się do tego również działalność literacka i publicystyczna Elizy Orzeszkowej.

\section{KILKA FAKTÓW Z ŻYCIA PUBLICYSTKI I POWIEŚCIOPISARKI}

Eliza Orzeszkowa - powieściopisarka, nowelistka, publicystka, działaczka społeczna i propagatorka pozytywizmu - urodziła się w 1841 r. w Milkowszczyźnie w pow. grodzieńskim. Była córką prawnika Benedykta Pawłowskiego i Franciszki Kamieńskiej. Początkowo kształciła się w domu, doskonale znała języki francuski i niemiecki. Bardzo wcześnie straciła ojca. Matka ponownie wyszła za mąż, a gdy dziewczynka miała 10 lat, zmarła jej jedyna siostra. Wówczas Eliza została oddana na pensję Sakramentek w Warszawie. Poczucie osierocenia towarzyszyło jej przez 
całe dzieciństwo, a „niedosyt ciepła matki, brak oparcia i życiowego doświadczenia osoby najbliższej” odegrał znaczącą rolę w jej dalszym życiu (Poczobut-Odlaniecki 2007, s. 5). Przyszła pisarka już w szkole zdobyła opinię „literatki”, podobnie jak inna uczennica tej pensji Maria Wołowska (późniejsza Konopnicka). Po ukończeniu przez Elizę pensji matka wydała ją za mąż za znacznie od niej starszego ziemianina, Piotra Orzeszkę. Młodzi zamieszkali w Ludwinowie na Polesiu. Tam Eliza zorganizowała szkółkę dla dzieci wiejskich. Wtedy też podjęła pierwsze poważniejsze próby literackie. Podczas powstania styczniowego $1863 \mathrm{r}$. pomagała powstańcom. Po zesłaniu męża na Syberię i utracie Ludwinowa na skutek represji popowstaniowych E. Orzeszkowa zamieszkała w majątku rodziców w Milkowszczyźnie i kontynuowała tam pracę oświatową. W 1866 r. Eliza zadebiutowała w „Tygodniku Ilustrowanym”. W opublikowanej w „Tygodniku Romansów i Powieści” w latach 1869-1870 powieści „Pan Graba” występowała przeciwko nierozerwalności małżeństwa, opowiadała się za pracą organiczną, idealizowała ludzi nauki i zaradnych ziemian. Pisała również o zdeklasowanej inteligencji i ziemiaństwie pozbawionym dotychczasowych podstaw bytu, szwaczkach, biedocie żydowskiej, różnych pechowcach, nieślubnych dzieciach. Lata 1886-1888 to najświetniejszy czas w twórczości pisarki. 15 marca 1887 r. literaci warszawscy uczcili 20-lecie jej pracy pisarskiej wręczeniem symbolicznego złotego pióra. Po sprzedaniu Milkowszczyzny E. Orzeszkowa zamieszkała w Grodnie. W 1894 r. wyszła ponownie za mąż za Stanisława Nahorskiego i zamieszkała w Warszawie. Tam Eliza zajęła się działalnością społeczno-filantropijną i oświatową. Do 1896 r. dla kilkunastu dziewcząt prowadziła wykłady z literatury i kultury polskiej, które nazywała żartobliwie uniwersytetem. Po śmierci męża do opustoszałego dworku zapraszała dziewczęta z domów inteligenckich i ziemiańskich - mieszkając u niej, pomagały jej w działalności społeczno-filantropijnej, m.in. prowadziły tajną czytelnię. Pisarka zmarła w 1910 r. w Grodnie (Kieniewicz 1979, s. 312-316).

\section{KWESTIA KOBIECA W UJĘCIU ELIZY ORZESZKOWEJ}

Sprawa emancypacji kobiet była w II połowie XIX w. na tyle istotna, że ,jako kobieta, z natury rzeczy musiała Orzeszkowa zwrócić uwagę na sprawy płci swojej [...] i poświęcić jej znaczą część swego talentu" (Nitowski 1897, s. 18). Zagadnienia te pisarka poruszała w opowiadaniach, nowelach, powieści Marta oraz w tekstach publicystycznych. Wobec kwestii kobiecej zajmowała stanowisko umiarkowane, licząc się z warunkami życia polskiego społeczeństwa. Wiedziała, że emancypacja była utożsamiana przez znaczną cześć polskiego społeczeństwa „z brakiem przyzwoitości, pogardą obowiązków rodzinnych i pozbyciem się najmilszej z zalet 
- prostoty", dlatego też emancypantki określano jako kobiety kapryśne, rozpustne, „puste w próżnowaniu” (Orzeszkowa 1874, s. 7). Jednocześnie zdawała sobie sprawę, że tylko właściwe rozwiązanie kwestii kobiecej mogło pomóc w przezwyciężeniu wielu narastających problemów społecznych. Do najważniejszych zaliczała niewłaściwe wychowanie młodzieży, braki w wykształceniu dziewcząt i ich przygotowaniu do podjęcia pracy zarobkowej oraz trudności w znalezieniu zatrudnienia przez kobiety $\mathrm{z}$ warstw średnich, które same musiały zarobić na utrzymanie. Zwracała uwagę, że na ziemiach polskich, podobnie jak w wielu innych krajach europejskich, „niezdolność do zarobkowania z jednej strony, a umyślne tamowanie wielu dróg do pracy z drugiej zrodziło proletariat liczny i kwestię kobiecą na nowe skierowało tory" (Nitowski 1897, s. 18). Nie żądała dla kobiet „nauki uniwersyteckiej, katedr profesorskich, stopni doktorów", nie pisała o kwestii zdolności fizycznych i duchowych kobiet, nie domagała się bezwzględnego równouprawnienia obu płci, ale próbowała „skierować całą sprawę na grunt czysto praktyczny”, nawoływała, „by środkami takimi, jakimi społeczeństwo może rozporządzać, zabezpieczyć materialny byt kobiety przez otwarcie jej pola do pracy i dać jej wykształcenie najpierw ogólne, a następnie fachowe” (Nitowski 1897, s. 29). Chciała „widzieć kobietę nie uczoną, rozprawiającą o filozofii, ale dobrą i rozumną żoną, matką i obywatelką" (Nitowski 1897, s. 29). Najbliższa przyszłość pokazała, że E. Orzeszkowa się nie myliła, gdyż już w ostatnich latach XIX w. „kwestia wychowania racjonalnego i samodzielnej pracy jednostek stała się jednym z najważniejszych haseł" (Nitowski 1897, s. 29).

Pisarka podkreślała, że emancypację należy rozumieć jako zdjęcie z kobiet ciążącego im jarzma, wyzwolenie $\mathrm{z}$ więzów. Nie chodziło przy tym o więzy małżeńskie i rodzinne, gdyż polskie kobiety wcale nie dążyły do pozbycia się ich - w klasach średnich mężowie przeważnie nie tyranizowali swoich żon, a przeważająca część dziewcząt intuicyjnie wyczuwała, że „w rodzinie leżą najważniejsze powinności, najwznioślejsze zadania i najczystsze szczęście kobiety" (Orzeszkowa 1874, s. 10). Nie o takie jarzmo więc chodziło. Kobiety powinny natomiast wyzwolić się „od słabości fizycznej bardziej narzuconej niż od natury wziętej, od braku sił moralnych na samoistne i logiczne życie, od klątwy wiecznego niewolnictwa i anielstwa, od wypatrywania z cudzej ręki kawałka powszedniego chleba, od wiecznego zamykania przed nimi dróg poważnej i użytecznej pracy" (Orzeszkowa 1874, s. 12). E. Orzeszkowa sądziła, że zbyt duże wywyższanie i idealizowanie kobiet nie sprzyja ich dobru, gdyż może spowodować, że będą traktowane jako istoty anielskie, dlatego też nie uczono ich prozaicznych czynności codziennego życia. Tymczasem żadna nie powinna godzić się na to, aby traktowano ją jako „niepełnoletnią, naturą swoją więcej zbliżoną do kwiatu, lalki, anioła niż człowieka" (Orzeszkowa 1874, s. 17). Przeznaczeniem kobiety podobnie jak mężczyzny jest być przede wszystkim człowiekiem, a dopiero potem żoną, matką, gospodynią domu. E. Orzeszkowa 
uważała, że „kobiety, przy odpowiednich przekonaniach i dążnościach, mogą być bardzo zdolne do wyprostowania w kierunku dobra moralnego zbyt wykrzywionej w kierunku dóbr materialnych cywilizacji współczesnej” (Orzeszkowa 1900a, s. 6). Muszą jednak najpierw podjąć trud własnego udoskonalenia moralnego. Mogą wówczas „wnieść w społeczeństwa właściwy sobie sposób pojmowania i stosowania praw moralnych" (Orzeszkowa 1900b, s. 24). Na początek powinny jednak nauczyć się dobrego wypełniania przyjętych na siebie obowiązków, aby mogły używać przysługujących im praw, gdyż „każdemu prawu towarzyszy obowiązek”, a „trudność obowiązku zwiększa się w miarę ważności prawa”, zaś „prawa należą się tym tylko, którzy chcą i umieją spełniać obowiązki” (Orzeszkowa 1900c, s. 83). Takie podejście do obowiązków gwarantowało, zdaniem E. Orzeszkowej, właściwe traktowanie kwestii kobiecej oraz jej pozytywny wpływ na losy zarówno jednostek, jak i całego społeczeństwa.

\section{OBRAZ KOBIETY W UTWORACH ELIZY ORZESZKOWEJ}

Pisarka w swych utworach bardzo sugestywnie przedstawiła obraz młodych dziewcząt przygotowywanych głównie do wyjścia za mąż, ale już nie do realizowania zadań związanych z założeniem rodziny, kształconych w sposób konwencjonalny, próżnujących i z utęsknieniem oczekujących tego, kto ich wybawi od nudy codziennego panieńskiego życia. Ostrzegała przed niebezpieczeństwami płynącymi z takiego wychowania, z wyposażania młodych panien w bardzo okrojoną wiedzę, rozwijania talentów w sytuacji, gdy dziewczyna ich nie posiadała, unikania uczenia jej tego wszystkiego, co w życiu mogło się okazać pożyteczne - w imię konwenansu i przekonania, że dobrze wychowanej panience „nie wypada”. Obrazek młodych rozbawionych kobiet, interesujących się głównie strojami i szukaniem „dobrej partii”, a w rzeczywistości nudzących się i pragnących jak najszybciej wyjść za mąż, aby uzyskać jak najwięcej wolności, przedstawiła w powieści Pamiętnik Wacławy. Od tytułowej bohaterki powieści wymagano znajomości języków angielskiego i francuskiego, „które są powszechnie używane po salonach” (Orzeszkowa 1988, s. 42) oraz gry na fortepianie - ale tylko takich utworów, które spodobają się innym. „Do ich to upodobań i skali artystycznej zastosować się w twej grze powinnaś, inaczej okrzyczą cię za nieumiejętną w muzyce, co będzie z wielką twoją szkodą, bo każda dobrze wychowana panna ładnie grać powinna” - przestrzegała bohaterkę matka. I dalej: „celem umiejętności grania jest możność przyjemnego zabawienia towarzystwa, w jakim znajduje się młoda osoba” (Orzeszkowa 1988, s. 44). Dziewczynę uczono też zajmowania się robótkami ręcznymi, zwłaszcza wyszywaniem na kanwie i haftem, gdyż „nieprzyzwoitym jest, aby dobrze wychowana panna siedziała 
w salonie z założonymi rękami i mieszała się do rozmów starszych, albo głośno wypowiadała swoje zdanie" (Orzeszkowa 1988, s. 85) oraz wymagano rezygnacji ze zbyt wnikliwych dociekań podczas rozmów z najbliższymi, gdyż jeżeli „ludzie skłonność tę w tobie spostrzegą, nazwą cię pedantką i panną emancypowaną" (Orzeszkowa 1988, s. 45). Matka Wacławy sądziła, że kobiety „nie mają potrzeby ślęczyć nad naukami, chyba jeśli się kształcą na guwernantki” (Orzeszkowa 1988, s. 42), powinny raczej dążyć do zrobienia dobrej partii, tj. zdobycia męża, który posiada odpowiednie stanowisko społeczne, czyli właściwe nazwisko i znaczny majątek (Orzeszkowa 1988, s. 60-61). Podobnego zdania było większość matek dorastających córek $\mathrm{z}$ warstw średnich i dopiero ruina majątkowa lub śmierć mężczyzny utrzymującego rodzinę weryfikowała ich poglądy. Wiele młodych dziewcząt wychodziło za mąż za pierwszego mężczyznę, który poprosił o ich rękę, jeśli tylko posiadał określoną pozycję społeczną. Jedna z nich tak mówiła przyjaciółkom o własnym „szczęściu” związanym z zamążpójściem: „nie bardzo ja w to wierzę [...], abym miała po ślubie zapłonąć gorącą miłością do mego przyszłego małżonka [...], ale nie mam do niego antypatii i uważam go za dobrego i poczciwego człowieka. Przy tym zostając jego żoną otrzymam pewność, że nie będę już nigdy starą panną [...]. Jako mężatka będą miała niezależną w świecie pozycję, swobodę rozporządzenia się wszystkim, co będzie do mnie należało i mnóstwo przyjemności, rozrywek, zabaw" (Orzeszkowa 1988, s. 385). Wacława miała jednak mądrego ojca, profesora uniwersytetu, który sądził, że „każdy człowiek powinien posiadać wyłączną jakąś umiejętność i szczególne do czegoś zamiłowanie, jeśli chce przyszłość swą zabezpieczyć i od materialnych, i od moralnych niedostatków" (Orzeszkowa 1988, s. 158). Jego zdaniem dotyczyło to również kobiet. Wacławę pociągała nauka, zdobyła więc gruntowne przygotowanie do zawodu nauczycielskiego, jednak pomimo to nie otrzymała pożądanych propozycji pracy. Uzyskała wprawdzie dobrze wynagradzane lekcje muzyki i języków obcych, jednak była kobietą, więc nie mogła nauczać historii i nauk przyrodniczych pomimo posiadanego w tym kierunku przygotowania. Dopiero po dłuższych poszukiwaniach znalazła rodzinę, w której matka pragnęła, „aby jej córki otrzymały tak wszechstronne i gruntowne umysłowe wykształcenie, iżby na nim stale oprzeć się mogła moralna ich strona" (Orzeszkowa 1988, s. 240). Dzięki temu dziewczyna mogła zapewnić sobie środki utrzymania.

W znacznie trudniejszym położeniu znalazła się bohaterka opowiadania Julian$k a$. Jej problem polegał na tym, że posiadała jedynie niewielkie kwalifikacje, mogła więc zostać guwernantką „na początki” (Orzeszkowa 1971a, s. 59). A takich kobiet wśród przedstawicielek zubożałego ziemiaństwa i szlachty było wiele. Dodatkowym problemem Julianki była mała córeczka. Nawet jeśli udało się zdobyć kobiecie samotnie wychowującej dziecko posadę guwernantki i „wszelkie wygody” - „bo 
przecież gdzie guwernantka jest, to już i obiad co dzień, i szklanka herbaty, i ciepły pokój być musi”, chociaż niewielka pensja wystarcza jedynie, „aby móc jako tako przyodziać się", to zawsze pojawiał się problem: „a co z dzieckiem będzie?” (Orzeszkowa 1971a, s. 63, 66).

Samotną matką była również tytułowa bohaterka powieści Marta, która „urodziła się w dworku szlacheckim, niezbyt wspaniałym i bogatym, ale ozdobnym i wygodnym”, jej matka „była kobietą piękną i dobrą, ojciec człowiekiem ukształconym i także dobrym”, a Marta, ich jedyne dziecko, „wzrastało śród miłości ludzi i pieszczot dostatku" (Orzeszkowa 1979, s. 12). Dziewczyna wyszła za mąż z miłości za człowieka dobrego, pracowitego, który otoczył ją dostatkiem, ale mało przewidującego, więc po jego śmierci kobieta utraciła podstawę materialnego bytu własnego i swojego dziecka. Marta „nie była przyzwyczajoną do widoku ludzi szukających zarobku, upędzających się za kęsem chleba”, sądziła, że praca jest czymś, „po co nachylić się tylko trzeba, aby osiągnąć przedmiot upragniony". Jednocześnie nigdy nie zastanawiała się nad tym, co potrafi robić dobrze. „Nie była przyzwyczajona do rachowania się z posiadanymi zasobami umysłu, wiedziała tylko o tym, że to, co umiała, było zupełnie wystarczającym dla kobiety, zostającej w tych położeniach, w jakich ona zostawała, dla córki szlacheckiej, dla żony urzędnika" (Orzeszkowa 1979, s. 28). Niestety, okazało się to niewystarczające do tego, aby mogła czegokolwiek nauczać innych. Ponadto niektórych przedmiotów, np. geografii, historii powszechnej i historii literatury polskiej, nauczali głównie mężczyźni, więc w tym zakresie nie miała możliwości znalezienia pracy. Dowiedziała się też, że „taka tylko kobieta zdobyć sobie może zarobek dla życia dostateczny i los swój od wielkich cierpień i nędz ochronić, która posiada wysokie udoskonalenie w jakiejkolwiek umiejętności lub prawdziwy jaki i energiczny talent. Wszelkie początkowe wiadomości i mierne uzdolnienia nie zdobywają nic wcale albo, co najwięcej, zdobywają suchy i twardy kęs chleba, rozmoczony chyba w łzach i okraszony - upokorzeniami" (Orzeszkowa 1979, s. 40). Bohaterka zdumiona pytała, dlaczego mężczyźnie w podobnej sytuacji „pozwolonym by było użytkować dla siebie i swoich wszystko, wszystko, cokolwiek by posiadał w zasobach swego umysłu”, a ona musi ograniczyć się do umiejętności gry na fortepianie i znajomości języków obcych (Orzeszkowa 1979, s. 40). Jednocześnie zapytywała siebie: „Dlaczego nie dali mi tego, czego dziś wymagają ode mnie, dlaczego wymagają ode mnie tego, czego mi nie dali!" (Orzeszkowa 1979, s. 151). Pytała dalej: „Dlaczegóż ludzie wymagają, abym żyła o własnej sile, skoro mi jej nie dali? dlaczegóż mi nie dali siły, skoro jej teraz wymagają ode mnie?” (Orzeszkowa 1979, s. 217). Jej przyjaciółka z dzieciństwa, Karolina, która pomimo młodego wieku wiele w swoim życiu doświadczyła, wyjaśniała jej: „Patrz na mężczyzn. Każdy z nich żyje na świecie sam przez się, nie potrzebuje, aby dopisywano doń jakąś cyfrę dlatego, aby przestał być zerem. Kobieta jest zerem, jeśli 
mężczyzna nie stanie obok niej jako cyfra dopełniająca. Kobiecie dają błyszczącą oprawę [...] Jeżeli nie znajdzie dla siebie nabywcy albo znalazłszy utraci go, pokrywa się rdzą wiecznej boleści, plamami beznadziejnej nędzy, staje się na powrót zerem, ale zerem chudym z głodu, trzęsącym się z zimna [...] Nie ma dla niej ani szczęścia, ani chleba bez mężczyzny. Kobieta musi koniecznie uczepić się, w jakikolwiek sposób uczepić się mężczyzny, jeśli chce żyć" (Orzeszkowa 1979, s. 168). W tych słowach przedstawiła bolesną prawdę, która dotyczyła znacznej rzeszy kobiet pozbawionych opieki mężczyzn i zmuszonych szukać środków do życia. E. Orzeszkowa pisała: „Kobiety wierzą ślepo; kochają, poświęcają się, hodują dzieci, bawią się... spełniają zatem wszystko, co świat spełniać im nakazuje, a jednak świat krzywo jakoś na nie spogląda" (Orzeszkowa 1979, s. 5). Sądziła, że od początku dziewczętom stawiane są niewłaściwe cele życiowe: „Zaledwie odrósłszy od ziemi słyszymy już, że przeznaczeniem naszym będzie kochać jednego z panów stworzenia; podlotki, marzymy o tym panu i władcy każdego wieczora [...], każdego poranka [...] marzymy i wzdychamy" (Orzeszkowa 1979, s. 6).

Tymczasem życie zubożałych kobiet było walką o przetrwanie własne i swoich bliskich, chociaż często nie posiadały do niej potrzebnych umiejętności. Niektóre kobiety kosztem własnego zdrowia starały się same zdobyć niezbędne do pracy zawodowej przygotowanie. Taki trud podjęła panna Antonina, tytułowa bohaterka kolejnego opowiadania. Pracując jako guwernantka i zdając sobie sprawę z braków w posiadanej wiedzy, „długie godziny nocne i poranne przesiadując nad stołem obładowanym różnego rodzaju podręcznikami i metodami, kształciła się z taką żarliwością, że żółtość cery jej i kościstość kibici czyniły szybkie i widoczne postępy” (Orzeszkowa 1971b, s. 100). Niestety po jakimś czasie okazało się, że „przez długie lat kilkanaście wyobrażając sobie, że kształci się, czyniła nie wiedzieć co” (Orzeszkowa 1971b, s. 102). Nadmierna praca, niewielkie zarobki i trudne warunki mieszkaniowe spowodowały, że w wieku czterdziestu kilku lat trafiła w ciężkim stanie do szpitalnego przytułku. Pomimo wielu starań i wysiłku nie zdołała osiągnąć stawianego sobie celu, gdyż nikt nie pokierował właściwie jej pracą.

\section{KRYTYKA PRZYGOTOWANIA DZIEWCZĄT Z WARSTW ŚREDNICH DO ICH PRZYSZŁYCH OBOWIĄZKÓW}

Dziewczynce od najmłodszych lat wpajano, że „stworzona jest, aby być żoną, matką, gospodynią" (Orzeszkowa 1874, s. 18), powinna się więc poświęcać dla innych, zaprzeć samej siebie. Niemal każda młoda dziewczyna uważała małżeństwo za wieczne szczęście, natomiast nic nie wiedziała o jego zadaniach i związanych z nim obowiązkach. Czekała więc na męża i miłość, ale przeważnie nie rozumiała swego 
posłannictwa. Nie widziała celu swojego życia, nie miała świadomości czekających ją przeszkód i przeciwności (Orzeszkowa 1874, s. 18-20). Często decyzję o jej małżeństwie podejmowali za nią inni - przeważnie rodzice, niejednokrotnie decydował przypadek - kandydat, który jako pierwszy poprosił o jej rękę. Aby zapobiec takim sytuacjom, E. Orzeszkowa przytoczyła rady Edouarda de Laboulaye’a, kierowane pod adresem młodym dziewcząt: „Nade wszystko wybieraj człowieka, którego szanujesz i który myśli tak, jak ty; wybieraj tak, abyś mogła być dumną, ojca twoich dzieci. Miłość ulatuje z czasem, wiara w siebie wzajemna i szacunek zostają przy ognisku domowym i dojrzewając stają się czymś nad miłość nawet słodszym i zdrowszym" (Orzeszkowa 1874, s. 24).

Eliza Orzeszkowa krytykowała rodziców, którzy roztaczali przed córkami wizje szczęścia małżeńskiego, a zupełnie nie przygotowywali ich na trudy codziennego życia i nie wyrabiali wytrwałości w dążeniu do realizacji stawianych celów. Przekonywała, że w ten sposób unieszczęśliwią córki, które nie założą własnej rodziny i przez resztę życia będą opłakiwać nielitościwy los, a często również przymierać głodem na łasce najbliższych, gdyż nie potrafią samodzielnie żyć i zarobić na swoje utrzymanie. Publicystka przestrzegała: „Pozbawione rodzinnego życia, nie umiejąc wybrać sobie żadnego celu ani mogąc rozmiłować się w żadnym, czują w sobie samych próżnię, której nie mają czym zapełnić” (Orzeszkowa 1874, s. 45). Stara panna stawała się przedmiotem żartów i kpin, przypisywano jej wiele cech negatywnych. E. Orzeszkowa sądziła, że ich czasami śmieszne zachowania wynikały z braku celu w życiu. Wówczas kobiety samotne stawały się zazdrosne, zalotne i nadwrażliwe, okazywały innym swoją nienawiść. Gdyby mogły zająć się jakimś pożytecznym zajęciem, rozwijać swoje pasje i zainteresowania, niewątpliwie ich życie wyglądałoby inaczej. „A gdyby ten młyn duchowy znalazł w głowie kobiety myśl zdrową i oświeconą, wiedzę, znajomość społeczeństwa i jego potrzeb, miłość dla pięknej jakiej idei, pragnienie czynu i umiejętność pracowania, wytworzyłby zapewne [...] zamiast śmiesznego pożyteczne, zamiast złośliwego zbawienne, zamiast występnego cnotliwe" (Orzeszkowa 1874, s. 45). Nieroztropni rodzice nie przyczyniali się również do szczęścia córek, które wprawdzie znalazły męża, ale małżeństwo nie spełniło ich wygórowanych oczekiwań i pragnień. Zawiedziona w swych nadziejach kobieta przez resztę życia była „nieszczęśliwą istotą, chorą na ciele i duchu, zwiedzioną, rozczarowaną, nie zrozumianą przez świat i świata nie rozumiejącą", skazaną na to, aby „wyrzekać, chorować, nudzić się, szukać pociechy i rozrywki w próżnych, a rujnujących moralnie i materialnie połyskach”, przyczyniając się jednocześnie do rozpowszechniania w społeczeństwie poglądu, że „kobieta ani gruntownie myśleć, ani pożytecznie działać nie jest zdolną” (Orzeszkowa 1874, s. 32).

Za złamane życie wielu młodych kobiet E. Orzeszkowa czyniła odpowiedzialnym również społeczeństwo, które nie dawało dziewczętom szansy na zdobycie 
wykształcenia odpowiadającego temu, jakie uzyskiwali chłopcy, utrudniało też podejmowanie pracy zarobkowej. A przecież w Ameryce i w Anglii dziewczęta kształciły się na równi z chłopcami, zdobywały przygotowanie do wybranego zgodnie z własnymi uzdolnieniami zawodu, dbano też o ich rozwój fizyczny i moralny. Same też decydowały o wyborze przyszłego męża, dla którego były potem „szczęściem, prawdziwą towarzyszką życia, duszą i ozdobą jego domowego ogniska [...] pomocą, radą, pociechą i natchnieniem" (Orzeszkowa 1874, s. 40). Było to możliwe dzięki odpowiedniemu wychowaniu i uświadamianiu już kilkunastoletnim dziewczętom ich przyszłych zadań oraz stworzeniu warunków do zdobycia niezbędnego wykształcenia. Publicystka apelowała więc do wszystkich odpowiedzialnych za wychowanie młodego pokolenia: „Porzućmy niewolnicze naśladownictwo, rutynę, modę, wymagania, próżności, weźmy rozbrat z przesądami i wszelkimi fałszywymi uprzedzeniami [...] a kiedyś nasze córki nie zasiądą na błyskotliwym tronie salonów, nie będą przyjmować z radością hołdów utrefionych próżniaków, nie będą łaknęły kawałka chleba, nie umiejąc nań zapracować, nie staną się światu zgorszeniem lub pośmiewiskiem, ale świadome ludzkich i obywatelskich celów swoich i dążąc do nich z miłością i rozumem, posiądą w całej pełni godność człowieczą" (Orzeszkowa 1874, s. 50). A to właśnie powinno się stać głównym celem dążeń emancypacyjnych kobiet i całego społeczeństwa.

\section{POSTULATY ELIZY ORZESZKOWEJ W SPRAWIE KSZTAŁCENIA I PRACY KOBIET}

Wnikliwa obserwacja otaczającej rzeczywistości i świadomość krzywdy młodego pokolenia kobiet, wychowywanych i kształconych zgodne z nakazami tradycji skłoniły E. Orzeszkową do opublikowania w 1870 r. w czasopiśmie „Tygodnik Mód i Nowości" zbioru tekstów publicystycznych pod wspólnym tytułem Kilka słów o kobietach (Orzeszkowa 1870). Cztery lata później ukazało się ich wydanie książkowe (Orzeszkowa 1874). Część pierwsza rozważań dotyczyła celów i dróg życia kobiet, druga - ich wychowania, a trzecia - pracy zarobkowej. Publicystka zauważyła, że „kobiety nasze, odczuwając niezgodę zachodzącą pomiędzy ogólnym kierunkiem kształcenia się ich i życia a wymaganiami miejsca i czasu, skwapliwie przybiegają wszędzie, gdziekolwiek spodziewają się znaleźć słowo ostrzeżenia, wskazówkę postępowania, radę serdeczną a rozważną" (Orzeszkowa 1874, s. 1). Dlatego też starała się zaradzić tym potrzebom. Przekonywała czytelniczki, że „do rzeczy trudnych i tak długich jak życie, przygotowanie trudnym musi być i długim [...] aby myślą, uczuciem i czynem móc sięgnąć ku ideałom takim, spoczywać nie można ani na różach, ani na laurach, ani na marzeniach choćby najpiękniejszych, 
ale potęgę uczuć zwiększać i uszlachetniać należy światłem umysłu, godność moralną zabezpieczać pracą cierpliwą i umiejętną, wolę ćwiczyć do walk i prób w życiu niezbędnych” (Orzeszkowa 1874, s. 4). Wzywała kobiety: „uczmy się jak najwięcej, usiłujmy poznawać naturę naszą i świata, pracujmy nad czym kto może, ale gorliwie, cierpliwie i umiejętnie, bo na tej tylko drodze znajdując się, potrafimy rozumnie myśleć, wiernie kochać, cnotliwie żyć i skutecznie poświęcać się - bo wtedy tylko jeżeli ideały nasze zdobywać będziemy z pomocą wiedzy, woli, pracy i przez trzy te oręża bronionej cnoty, cierpienia nasze staną się lżejsze, błędy mniej liczne, zasługi większe, szczęście prawdziwsze i trwalsze, a chwila śmierci oświecona łagodnym i uspokajającym blaskiem dobrze przebytej przeszłości" (Orzeszkowa 1874, s. 4).

Kluczem „doli lub niedoli, siły lub słabości, zacności lub grzechu” było zdaniem E. Orzeszkowej wychowanie (Orzeszkowa 1874, s. 50). Sądziła, że jeśli kobieta będzie świadoma swoich celów i praw obywatelskich oraz ludzkich, jeśli będzie dążyła do nich z miłością i ogarniała je rozumem, stanie się dla wszystkich wokół jasno świecącą lampą. W ręku rodziców w pierwszej kolejności leży przyszły los ich córek, oni powinni „pierwszy kamień do szczęścia i zacności córek swych położyć” (Orzeszkowa 1874, s. 49). Wychowanie kobiet powinno obejmować harmonijny rozwój sfery fizycznej, umysłowej i moralnej, którym odpowiadają ciało, umysł i serce. Publicystka sądziła, że „zwichnięcie lub niedołężność jednej z tych władz osłabia i krzywi lub unicestwia dwie inne" (Orzeszkowa 1874, s. 51). Dlatego postulowała konieczność zadbania o prawidłowy rozwój fizyczny i zdrowie dziewcząt, zapewnienie im odpowiedniego wykształcenia ogólnego i zawodowego oraz zatroszczenie się o ich rozwój moralny. Ubolewała, że „w wychowaniu naszych kobiet, oprócz nielicznych wyjątków, strona fizyczna jest w zaniedbaniu zupełnym, umysłowo skrzywiona, niedostateczna i dla błahych, a zgubnych rozwijana celów, moralna piastowana wprawdzie troskliwie, gorliwie apostołowana, lecz wskutek słabości fizycznej i umysłowej nie przynosząca bynajmniej pożądanych owoców" (Orzeszkowa 1874, s. 64). Publicystka przekonywała czytelniczki, że kobiety „powinny uczyć się nie dla popisu i zdobycia męża, ale dlatego, aby posiadły światło i siłę moralną odpowiednią każdemu położeniu, w jakim by je los postawił" (Orzeszkowa 1874, s. 141). Muszą mieć dostęp do każdej nauki, zgodnej z ich uzdolnieniami i pozycją społeczną, do jakiej się przygotowują. Zachęcała dziewczęta szczególnie do kształcenia w zakresie nauk przyrodniczych i historii, gdyż sądziła, że mogą one wyrobić w młodej kobiecie „logiczne i praktyczne pojęcia, szeroki pogląd na rzeczy i prostotę” (Orzeszkowa 1874, s. 42). Za pożądane, chociaż mniej konieczne, pisarka uznała też kształcenie dziewcząt w językach obcych. Nie sprzeciwiała się wysłuchiwaniu przez wszystkie uczennice wykładów z teorii muzyki i rysunku, jednocześnie podkreślając, że praktyczne nauczanie tych przedmiotów powinno dotyczyć tylko dziewcząt szczególnie uzdolnionych $w$ kierunku artystycznym. Twierdziła, że dziewczęta, podobnie 
jak chłopcy, powinny kształcić się do 20-22. roku życia, a nie jak dotychczas zaledwie do 15. lub 17. Dodatkowe lata nauki (tzw. trzecią epokę kształcenia) należy poświęcić na gruntowne przygotowanie zawodowe młodej kobiety. Powinna ona wówczas dokładnie poznać samą siebie, ludzi i stosunki społeczne oraz kształcić się w wybranym przez siebie zawodzie. Jeśli kobieta w wyborze nauki i pracy nie kieruje się zdolnościami i pragnieniem stania się pożyteczną, ale fałszywą ambicją dążenia do zaszczytów lub największych korzyści fachowych, nie jest właściwie rozwinięta moralnie. E. Orzeszkowa przestrzegła: „Takie pychy i pretensje nie poparte zdolnościami odpowiednimi, wprowadzają w pracę kobiecą pierwiastek niedołęstwa i wytwarzają wśród kobiecego rodu inny znowu gatunek istot, które pozorami nauki i pracy maskują swoją rzeczywistą nieużyteczność, a nawet szkodliwość" (Orzeszkowa 1897, s. 20). Wskazywała, że nie należy też zapominać o rozwoju moralnym kobiety. Trzeba pracować „nad ulepszeniem serc, wzmocnieniem woli, wypracowaniem dobrych przyzwyczajeń i obyczajów", gdyż pierwiastki umysłowy i etyczny są równoważne, solidarne ze sobą (Orzeszkowa 1974, s. 5).

Człowiek powinien pracować, aby nauczył się pracy. Brano to pod uwage w kształceniu chłopców, którzy od najmłodszych lat słyszeli, że powinni mieć w życiu cel i dążyć do jego realizacji. Przestrzegano ich, że w drodze do realizacji zamierzeń napotkają na przeszkody, które jednak ich wzmocnią i nauczą pracować. Powinni więc poznać własne zainteresowania, zdolności i możliwości oraz wybrać własny cel istnienia. Tak samo należało postępować wobec dziewcząt. Publicystka była przekonana, że zdobyta wiedza i fachowe umiejętności przydadzą się niewątpliwie tej, która założy własną rodzinę, gdyż będzie mogła wspomóc męża w zdobyciu środków materialnych oraz będzie potrafiła racjonalnie gospodarować posiadanymi zasobami. Mąż zyska w niej nie tylko gospodynię domu i matkę dla swoich dzieci, ale również „żonę w prawdziwym i najszerszym słowa tego znaczeniu, to jest towarzyszkę, przyjaciółkę, współpracownicę w przedsięwziętym dziele" (Orzeszkowa 1874, s. 99). Będzie też potrafiła odpowiednio pokierować wychowaniem i kształceniem własnych dzieci. Jeśli nie założy rodziny, będzie zdolna do samodzielnego życia i znajdzie sobie cel (Orzeszkowa 1874, s. 45). Nie będzie zmuszona „polegać dziś na czyjejś pracy, a na przyszłość spekulować znowu na czyjąś pracę lub fundusz, [...] czekać na męża jak na zwiastuna wygodnej przyszłości albo szukać go w podróżach i po balach z chłodem w piersi, z zalotnym uśmiechem na ustach" (Orzeszkowa 1874, s. 209-210). Było to niewątpliwie poniżające dla kobiet, dlatego w imię wspólnego dobra powinny dążyć do poszerzania pola pracy, dostępnego płci pięknej. Wszak - pisała autorka Kilku słów o kobietach - „lepiej jest - uczciwiej i rozumniej - podjąć z odwagą ciężar trosk i trudów, przywiązanych do pracowitego istnienia, a czuć się samodzielną - spokojną o zapracowany byt codzienny spełniającą człowiecze i obywatelskie zadania, niż spędzić część życia w zabawach 
i łatwych dostatkach, na całą przyszłość zyskać ubóstwo i nieszczęście, gorzki chleb jałmużny i łzy próżnych żałości” (Orzeszkowa 1874, s. 218).

Eliza Orzeszkowa odegrała istotną rolę w podnoszeniu świadomości społecznej w tzw. kwestii kobiecej. Wyjaśniała przyczyny dążenia Polek do równouprawnienia w zakresie kształcenia i podejmowania pracy zarobkowej. Posługując się sugestywnie nakreślonymi postaciami swych bohaterek, pokazywała, do czego prowadził dotychczasowy sposób edukacji, oparty głównie na rozwijaniu „talentów” i znajomości języków obcych. Wskazywała na tragedię wielu młodych kobiet zmuszonych warunkami życia do podjęcia pracy, a niepotrafiących pracować. Zwróciła uwagę na zróżnicowany sposób wychowania dziewcząt i chłopców, dający tym ostatnim znacznie większą swobodę i możliwości rozwoju, a następnie szansę na wybór zawodu, zgodnego z ich zainteresowaniami i możliwościami. Rolę E. Orzeszkowej w upowszechnianiu i wyjaśnianiu kwestii kobiecej docenili już jej współcześni. Maria Czesława Przewóska pisała: „Prawidłowy rozwój ruchu kobiecego leżał jej na sercu, wielu twórczych pomysłów był rdzeniem, a rzetelnie myślicielski kierunek wskazań jej w tej dziedzinie, na bieg tych rzeczy u nas oddziaływał znamiennie” (Przewóska 1906, s. 3). Jan Nitowski chylił czoła „przed ogromem myśli i przed ogromem miłości, którą całkowicie na swoje społeczeństwo przelała i dzięki której więcej, niż ktokolwiek inny, poruszyła kwestii palących”, dając czytelnikom „pokarm pożywny i zdrowy, nie siejąc nigdy niezgody i nienawiści, a przeciwnie: nawołując nieustannie do pracy wspólnej w imię jednych ideałów, do zgody i miłości bratniej" (Nitowski 1897, s. 58). Julia Oksza (Kisielewska) widziała w E. Orzeszkowej kobietę, „która nas wiodła do światła i czynu, [...] strzegła znicza miłości ojczyzny w sercach młodzieży, [...] prawdzie dawała świadectwo, a umiłowała sprawiedliwość" oraz pozostawiła po sobie testament „wytrwania do ostatka i wierności w rzeczach małych [...] testament zdobywania każdego dobra - pracą duchową, szczerą, odważną, gorącą, testament wyrzeczenia i twardej odporności wobec wszelkich omamień zbytku i pozorów, testament nieugiętości i prostoty" (Oksza 1910, s. 230). Służbie społecznej poświęciła całe swoje życie. Nad jej grobem Józef Kotarbiński złożył hołd jej życiu i pracy: „Ona krzepiła ducha i siły niewiasty polskiej, kazała jej walczyć o lepszą dolę, przełamać wiekowe poniżenie, dobijać się należnego miejsca wśród zastępu pracowników dla przyszłości. Ona troszczyła się o losy młodych pokoleń, w których duszach tkwią ziarna przyszłych plonów pracy i pomyślności narodu" (Mowa... 1910, s. 247).

Obecnie kobiety mogą podejmować kształcenie na różnych szczeblach i w wybranych przez siebie kierunkach. Płeć nie determinuje też rodzaju wykonywanej pracy zawodowej. Istnieją oczywiście profesje, które z racji swojej specyfiki są częściej wykonywane przez mężczyzn, jednak nawet w zawodach typowo męskich (np. kierowcy samochodów ciężarowych) coraz częściej pracę podejmują także kobiety. 
Można więc sądzić, że obecnie tzw. kwestia kobieca nie istnieje, nie warto więc zajmować się tymi problemami. Trzeba jednak pamiętać, że zdobycie przez dziewczęta możliwości swobodnego wyboru kierunku kształcenia i kariery zawodowej było okupione trudami i cierpieniem całej rzeszy kobiet domagających się prawa do życia i stanowienia o własnym losie. Ich rzecznikami byli pisarze i publicyści, którzy przyczynili się do rozpropagowania idei emancypacji w społeczeństwie, a wyjaśniając przyczyny leżące u podstaw dążeń kobiet do równouprawnienia, zdobyli dla kwestii kobiecej licznych zwolenników. Warto więc pamiętać o ich dokonaniach.

\section{LITERATURA}

Kieniewicz S. (red.), 1979, Polski Słownik Biograficzny, t. XXIV/1, z. 100. WrocławWarszawa-Kraków-Gdańsk, Wydawnictwo PAN, 312-316.

Mowy, wygłoszone nad grobem Elizy Orzeszkowej w Grodnie 23-go maja 1910 roku, 1910, „Bluszcz” 23, 245-247.

Nitowski J., 1897, Eliza Orzeszkowa, „Bluszcz” 3, 18-19; 4, 28-29; 8, 58.

Oksza J., 1910, Jej testament, „Bluszcz” 22, 230.

Orzeszkowa E., 1870, Kilka słów o kobietach, „Tygodnik Mód i Nowości” 40, 1-3;41, $4-7 ; 42,4-6 ; 43,3-5 ; 44,4-6 ; 48,1-4 ; 49,3-6 ; 50,3-5 ; 51,2-4 ; 52,4-7 ; 53,1-4$. Orzeszkowa E., 1874, Kilka słów o kobietach. Warszawa, Wydawnictwo Czytelnik. Orzeszkowa E., 1897, W kwestii równouprawnienia kobiet wobec nauki, pracy i dostojności ludzkiej (List otwarty do kobiet niemieckich), „Bluszcz” 1, 4-5; 3, 20-31; 10,75 .

Orzeszkowa E., 1900a, List do kobiet niemieckich i O Polce - Francuzom. Warszawa, Wydawnictwo Księgarnia J. Fiszera.

Orzeszkowa E., 1900b, List otwarty do kobiet niemieckich w kwestii równouprawnienia kobiet wobec nauki, pracy i dostojności ludzkiej. W: E. Orzeszkowa, List do kobiet niemieckich i O Polce - Francuzom. Warszawa, Wydawnictwo Księgarnia J. Fiszera, 9-39.

Orzeszkowa E., 1900c, O Polce - Francuzom. W: E. Orzeszkowa, List do kobiet niemieckich i O Polce - Francuzom. Warszawa, Wydawnictwo Księgarnia J. Fiszera, 41-83.

Orzeszkowa E., 1971a, Julianka (Obrazek miejski). W: E. Orzeszkowa, Opowiadania. Warszawa, Wydawnictwo Czytelnik.

Orzeszkowa E., 1971b, Panna Antonina. W: E. Orzeszkowa. Opowiadania. Warszawa, Wydawnictwo Czytelnik.

Orzeszkowa E., 1979, Marta. Lublin, Wydawnictwo Lubelskie.

Orzeszkowa E., 1988, Pamiętnik Wacławy, t. 1. Warszawa, Wydawnictwo Czytelnik. 
Poczobut-Odlaniecki S., 2007, Szlakiem Elizy Orzeszkowej i jej bohaterów - wiek później. Białystok, Wydawnictwo Prymat.

Przewóska M.Cz., 1906, Eliza Orzeszkowa w literaturze i w ruchu kobiecym. Zarys syntetyczny. Lwów, Wydawnictwo Księgarni $\mathrm{H}$. Altenberga.

Żmijewska E., 1910, Nad trumną Orzeszkowej. „Bluszcz” 23, 244-245.

\author{
CONTRIBUTION OF ELIZA ORZESZKOWA TO THE PROMOTION OF \\ WOMEN'S ISSUES AND SHAPING THE EDUCATIONAL ASPIRATIONS OF \\ YOUNG POLISH WOMEN IN THE SECOND HALF OF THE $19^{\mathrm{TH}}$ CENTURY
}

\begin{abstract}
In the second half of the $19^{\text {th }}$ century, in the Polish lands, the women's issue became an important social issue. It affected women of average social strata. This included issue of girls' education, preparing them for gainful employment and the jobs that are suitable for women in places where they would not represent competition for men. These issues were also raised by Eliza Orzeszkowa, a well-known writer and journalist. She advocated a thorough education of women in the direction corresponding to their abilities and interests. She demanded reform of the education of girls in the family, and especially taking care of their harmonious physical, mental and moral development. She drew attention to errors committed by parents and pointed out ways to fix them. Presenting in her novels and stories the fate of women who have been forced by the conditions of life to take up gainful employment and did not have the required preparation for it, emphasized the need to ensure that every girl would get professional training in the direction chosen by her. In journalistic texts, she indicated the purpose and methods of proper upbringing and education of female youth. Contribution of Eliza Orzeszkowa to the promotion of women's issue and shaping the educational aspirations of young Polish women in the second half of the nineteenth century is thus difficult to overestimate and therefore has become the subject of this discussion.
\end{abstract}

Keywords: Eliza Orzeszkowa, women's issue, girls' education, women's gainful employment 